\title{
サーモグラフィにおける腰部神経根障害の診断基準
}

\author{
久留米大学整形外科 \\ 相 良 正 志・永 田 見 生 \\ 宮 崎 信 平・井上 明生
}

\section{Reference Standard of Thermographic Analysis for Lumbar Root Compression Syndrome}

\author{
Masashi Sagara, Kensei Nagata, Shinpei Miyazaki and Akio Inoue
}

\begin{abstract}
Skin temparature measurements were carried out in 70 healthy subjects,and in 35 patients with lumbar disc herniation.In healty subjects, the degree of thermal asymmetry varied in different between each homologous regions of the body. The most of symptomatic patients had the manifestation of thermographic cold area coinciding with the pain distribution. When asymmetries exceeded 1 standard deviation from the mean temperature of homologous regions measured in healty subjects, the positive finding was $94 \%$ of the patients with lumbar disc herniation.

From these results, we consider that the temperature differences obtained in healthy subjects should be used as the reference standard for clinical diagnosis.
\end{abstract}

\section{目的}

近年, 医用サーモグラフィの臨床応用が盛んに行わ れているが，未だその体表温の異常を評価する診断基 準が明確にされていない. 今回, 腰部神経根障害の サーモグラフィにおける診断基準を作製するために， 臨床症状を認めない健常人と神経根障害群の体表温を 比較検討した。

\section{調 查 対 象}

臨床的に健常人と判断された正常群は 70 例で，男 性 61 例, 女性 9 例, 平均年齢 22.4 歳である。一方, 神経根障害群は片側単一椎間の腰部椎間板へルニア 35 例であり, 男性 24 例, 女性 11 例, 平均年齢 34.2 歳である．高位別では L4/5ヘルニア 25 例，L5/S 1 へ ルニア 10 例で, 全て MRI および脊髄造影検査等の画 像診断によって責任高位が確認され, 観血的治療が行 われた症例である。

\section{測定および評価方法}

全症例の両下肢体表に 18 力所の対称性の関心領域
を設定し，各領域の平均温度を求め，環境による影響 を少なくするために対称部位の平均左右温度差と標準 偏差で評価した（図１）。神経根障害群に対しては， 障害高位別に各領域の温度差を正常群と比較し,さら に疼痛, 知覚障害領域を部位別にマッピングしたもの を3つの診断基準で評価した。なお，測定に使用した 装置は日本アビオニクス TVS-3000であり，測定手準， 条件は学会基準に従った。

\section{結果}

\section{1 ）正常群の検討}

正常群では各領域間で平均左右温度差 0.15 から $0.25{ }^{\circ} \mathrm{C}$ ，標準偏差 0.12 から $0.22^{\circ} \mathrm{C}$ と，かなりの左 右差，領域間の差が存在した。 また左右差が最も大き い部位は足背部であり，下肢末梢側ほど左右差が大き い傾向にあった（図 2 ）。

2 ) 診断基準温度の設定

疼痛や知覚障害を訴える領域を正常例の平均皮虐温 と比較した．各領域において正常例の mean + 1SDを 越える左右差を温度異常の診断基準とした場合，臨床 症状と温度異常域の一致率は約 $94 \%$, + 2 SD を基 



ijij ijji

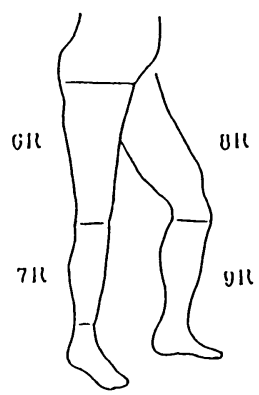

後 ilii

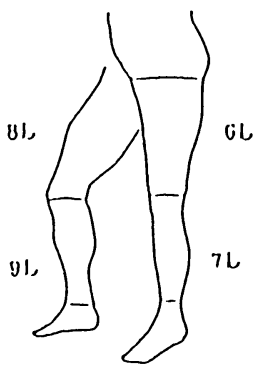

们! i ijii

図 1 Regions of interest (ROI's) on the skin surface
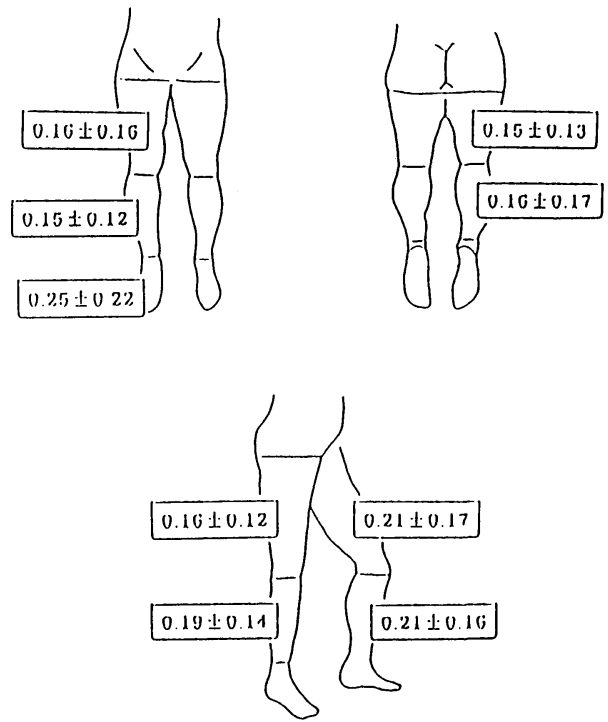

図 2 Asymmetries of temperature in normal control subjects
表 1 Consistency of thermatome with clinical symptom

\begin{tabular}{rll}
\hline \hline 正常例の mean + 1 S D & $:$ & $94 \%$ \\
+2 S D & $:$ & $59 \%$ \\
$+3 \mathrm{~S} \mathrm{D}$ & $:$ & $44 \%$ \\
$0.6^{\circ} \mathrm{C}$ の診断基準 & $:$ & $74 \%$ \\
\hline
\end{tabular}

表 2 Consistency of cold area

with clinical symptom

\begin{tabular}{lr}
\hline \hline 疼痛領域 & $96 \%(26 / 27)$ \\
知覚障害単独領域 & $45 \%(9 / 20)$ \\
Hypesthesia & $100 \%(9 / 9)$ \\
Dysesthesia & $0 \%(0 / 11)$ \\
\hline
\end{tabular}

準とした場合は約 $59 \%$ ，+3 SD を基準とした場合は $44 \%$ \%゙あった（表 1 ).

3 ) 臨床症状と冷温域の一致率

症状別の一致率を見ると冷温域は疼痛分布と最も一 致（96\%）していた。一方，知覚障害単独領域と冷 温域の一致率は $45 \%$ であり, 全てが Hypesthesia 例で, Dysesthesia 例では全て等温または高温域を示した（表 2 ).

\section{考察}

Thermography は生理機能検査のなかでも客観的 に，定量的評価が行える検査法として注目されてきた。 しかし, 体表温に影響を与える因子は多く, 単純に比 較できないこともあり，基準となる正常皮虐温を決め るまでには至っていない，そのため諸家の報告におい ても診断基準が一定していない. 正常人の体表温に対 する, Uematsu ${ }^{2)}$ や満淵 ${ }^{1)}$ らの詳細な検討では, か なりの左右差が存在すると報告している，今回の我々 の調査でも, 諸家の報告と同様にかなりの左右差と領 域間の差が存在し，末梢側ほどその程度は大きい傾向 にあった。

これまで温度異常の基準を諸家の報告に準じて, $0.6{ }^{\circ} \mathrm{C}$ の画一的な温度で全て評価してきたが, 正常例 に挑いてもかなりの領域間の差が存在することを考え ると false negative が多く生じている可能性がある. このため一つの診断基準で温度異常を判断するより， 領域別の診断基準を設けた方が妥当であると思われ た. 
そこで実際の診療に役立つ診断基準を求めるため に, 症状を部位別に 3 つの基準で評価した. その結果, 正常例の mean + 1SD を基準とした場合，臨床症状と 温度異常域の一致率は約 $94 \%$ で最も高率であった. 従

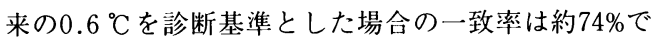
あり, mean + 1SDを越える左右温度差を診断基準と した場合が false negative や false positive の危険性が 最も少ない有効な診断基準であると思われた。

また, 症状別の一致率を見ると, 冷温域と知覚障害 単独領域の一致率は $45 \%$ であり, Dysesthesia 例では 全て等温または高温域を示した. Dysesthesia 領域に おいては, 有意の左右温度差として表現されにくい傾 向があるため,この領域にたいする評価には特に注意 が必要である.

体表温の非対称性を引き起こす因子として, 脈管, 内分泌, 神経系の病的因子を除いても, 測定時刻, 環 境, 体格, 年齢など様々な因子が関与している. 今回 対象とした正常群は, 平均年齢 22.4 歳と比較的若年 層であり，年蹂による差が存在するか否かについては 検討していない. 今回調査した腰部椎間板へルニアは 若年者に多く, 本報告においては年㱓的問題はないと
思われる．しかし，左右差による検討のみでは，検査 時の環境条件，利き足，スポーツ歴などの影響因子の 関与を完全に消去しきれず, 問題を残すところである.

\section{ま と め}

1) 正常例においても各領域にかなりの左右差と領域 間の差が存在するため，一つの診断基準で温度異常 を判断するより領域別の診断基準を設定するのが妥 当である.

2 ）診断基準を正常例の mean + 1SD を越えるものと するのが最も有用である.

3 ) 知覚障害単独領域のうち Dysesthesia 領域の評価 には注意が必要である。

\section{文献}

1）満淵邦彦ら：正常例における体表温の左右差の検 討. Biomedical Thermography, $7: 66-68,1987$.

2) Sumio Uematsu: Symmetryof Skin Temperature Comparing One Side of the Body to the Other. Thermology, 1: 4-7, 1985. 